\title{
An Empirical Study of Hybrid DEA and Grey System Theory on Analyzing Performance: A Case from Indian Mining Industry
}

\author{
Lai-Wang Wang, ${ }^{1}$ Thanh-Tuyen Tran, ${ }^{1,2}$ and Nhu-Ty Nguyen ${ }^{2}$ \\ ${ }^{1}$ Department of Industrial Engineering and Management, National Kaohsiung University of Applied Sciences, No. 415, JianGong Road, \\ Sanmin District, Kaohsiung 807, Taiwan \\ ${ }^{2}$ International Relations Office, Lac Hong University, No. 10 Huynh Van Nghe, Bien Hoa, Dong Nai 71000, Vietnam
}

Correspondence should be addressed to Thanh-Tuyen Tran; copcoi2@gmail.com

Received 26 August 2014; Accepted 19 November 2014

Academic Editor: Sebastien Thomassey

Copyright (C) 2015 Lai-Wang Wang et al. This is an open access article distributed under the Creative Commons Attribution License, which permits unrestricted use, distribution, and reproduction in any medium, provided the original work is properly cited.

\begin{abstract}
India, which has long been recognized as a well-endowed nation in natural mineral resources, is a major minerals producer. According to the report of Indian Ministry of Mines 2013, Indian mining and metals sector ranked the fourth among the mineral producer countries, behind China, United States, and Russia and had in fact led the economy into recovery from the global financial crisis. Since this industry has turned into a significant issue, this paper attempts to rank the performance of 23 Indian mining and metal companies and to evaluate and measure the productivity change of these sectors during different time periods (2010-2014). Besides, the authors would like to choose one advanced model of MPI to see the performance of these companies in the past-present period and the 4-year future period (2015-2018) by using forecasting results of Grey system theory. The results revealed that from the past to future period the National Mineral Development Corporation, Hindalco Industries Limited, and Coal India always keep their highest best rankings among 23 DMUs regarding performance scores. This study contributes better insights of Indian mining industry as it is the core of the economy.
\end{abstract}

\section{Introduction}

India is a growing economy, and its mineral and energy demands are likely to grow fast [1]. As one of the world's leading mineral producers, India is endowed with a rich resource base of several metallic, nonmetallic, and fuel minerals that offer huge opportunities to both domestic and global players for investment. India's mineral policy is also aimed at attracting foreign investment and encouraging foreign technology and foreign participation in exploration mining for high value. Report of Indian Ministry of Mines (2012-2013) revealed that the country's mining and metals sector has contributed to lead the national economy into recovery out of the period time of global financial crisis of 2007-2009. The total value of mineral production during 2012-2013 has been estimated at rupees (Rs.), 2006 billion reflecting an increase of around $11.83 \%$, while the sector's share in the total gross domestic product (GDP) has remained flat at $2 \%$ over the last 15 years. In addition, financially, this sector has performed reasonable well in the last few years, as reflected in the volume and profit growth of some large mining companies, namely Coal India, National Mineral Development Corporation, and Manganese Ore India.

Since around the turn of the century, the country is a leading producer of certain key minerals such as iron ore and bauxite; thus, it is considered as a key segment of Indian economy [2]. In the year 2013, mining industry provides daily direct employment to about 1 million people and is largely fragmented into small scale operational mines. The number of small mines in India was 3,108 in 2012-2013 as against 3,236 in the previous year. However, during this period of time, the public sector or Government-owned Corporation continued to play a dominant role in mineral production accounting for $67.7 \%$, while small mines, mostly from the private sector, continued to be operated manually either as proprietary or as partnership ventures.

Previous studies on measuring productivity of Indian coal mining activity have shown a steady increase and performance of the different companies also depends on the state of technology and economic efficiency of the regions 
Kulshreshtha and Parikh [3]. This study attempts to analyze performance of Indian mining activity in the various coal producing companies across the country from 2010 to 2014. The objective is to derive performance measures for the different mining companies into adopting a right approach to policy decisions to improve performance.

One way to propose productive efficiency is the ability to combine inputs and outputs in optimal proportions at their prevailing prices, under a behavioural assumption for the decision making units (DMUs), for example, cost minimisation, revenue maximisation, and so forth [4]. A nonparametric approach to frontier analysis, the DEA, is used in this paper in order to distinguish between well-performing companies of coal mining and the inefficient ones. With DEA methodology, the author evaluates the enterprises' performance by classifying input and output data to propose productive efficiency. Moreover, Grey system theory is also used in this study for the purpose of forecasting companies' productivity for the next four years (2015-2018) concisely.

Super SBM method is also applied in this study to rank companies' performance and this method is followed by Malmquist nonradial and Malmquist radial models. DEA can be applied to measure the productivity of multiple input and output decision-making units, whereas the DEA-based Malmquist productivity index can be used as a tool for measuring the productivity change of coal mining sectors during different time periods (2010-2014). At the same research procedure, the author also aims to test significant differences between MPI models and Malmquist nonradial and radial models to choose which model is effective for evaluating companies' performance in recent years and future time.

\section{Literature Review}

The study of Kulshreshtha and Parikh [5] was an attempt that has been made to do an in-depth analysis of the productivity growth in the Indian coal sector during the period 19801992. Total factor productivity was calculated from the output and input indices for Coal India Ltd. Results of the analysis indicated that the labor productivity increase of around 37.6\% was achieved. Study of the individual subsidiaries indicated that companies with larger share of underground mines have shown slower growth in productivity. The underutilization of capital, surplus labor, power shortages in the underground mines, inability to adapt to modern technologies, and a pricing structure of coal were the reasons of poor performance of Coal India Ltd.

Kasap et al. [6] conducted a study which aimed to examine the effects of noncontrollable factors as well as input parameters on the efficiency performances of eight enterprises within Turkish Coal Enterprises (TCE) from 2005 to 2007. For each enterprise, the outputs included the production sold and the total income; the controllable inputs consisted of investment expenditure, overburden stripping, and number of staff and the noncontrollable inputs consisted of total reserve and low heat values. Considering the noncontrollable inputs as a result of the analyses conducted with three-stage DEA model, it was determined that the average efficiency value of Turkish Coal Enterprises increased from $87.5 \%$ to $92.3 \%$.

In the study of Xue et al. [7], the authors used an inputoriented model to measure the energy consumption productivity change from 1999 to 2008 of fourteen industry sectors in China as decision-making units. The results showed that there are only four sectors that experienced effective energy consumption throughout the whole reference period. The other ten sectors experienced inefficiency in some two-year time periods and the productivity changes were not steady. The data envelopment analysis-based Malmquist productivity index provided a good way to measure the energy consumption and can give China's policy makers the information to promote their strategy of sustainable development.

Fang et al. [4] attempted to compare the technical efficiency performance of listed coal mining companies in China and the US using CCR and BCC models in the advanced DEA linear programming. The results showed that the level of relative efficiency in Chinese coal mining enterprises, regardless of total technical efficiency or decomposed pure technical and scale efficiency, is much lower than that in American coal firms.

In the study of Tsolas [8], the author presented DEA model combined with bootstrapping to assess performance in mining operations. Since DEA-type indicators based on nonparametric production analysis are simply point estimates without any standard error, the author provides a methodology to assess the performance of strip mining operations by means of a DEA bootstrapping approach. Although omitting undesirable output resulted in biased performance estimates, these findings were based on sample specific results and indicate that this bias is not statistically significant.

\section{Methodology}

3.1. Research Process. In this study, the author attempts to measure productive efficiency of 23 listed companies in India covering the period time from 2010 to 2014. The data are collected from the websites of Bombay Stock Exchange and Money Control that contain the financial data of individual Indian mining companies and these pages are currently considered as one of the India's number one financial portal [9-11]. In our study consideration, we skip some mining companies for which financial data have not been found on the websites. The selected companies chosen for this research are listed in Table 1. These mining sectors are named Decision Making Unit from DMU1 to DMU23, respectively.

Zhu [12] emphasized that levels of employees, assets, and equity may actually increase revenue and profit levels. Moreover, according to the study of T.-Y. Chen and L.-H. Chen [13], the elements of profitability; relative market position; change in profitability and cash flow; and growth in sales and market share, total expenditure, equity capital, net income, net profit, and EPS (earnings per share) are considered as key factors that contribute directly to the performance of companies. Table 2 presents in detail real stock market data collected 
TABLE 1: List of mining companies of India.

\begin{tabular}{|c|c|c|c|c|}
\hline Category & Name of Companies & Type & Sector & Financial index symbols \\
\hline \multicolumn{5}{|c|}{ Section 1: Companies listed on the website of Bombay Stock Exchange } \\
\hline DMU1 & Hindustan Copper Limited & Government owned & Mining and smelting & BSE: 513599; NSE: HINDCOPPER \\
\hline DMU2 & J \& K Mineral Development & State-owned enterprise & Minerals and metals & BSE: 526371; NSE: NMDC \\
\hline DMU3 & National Aluminium Company & Government owned & Aluminium metal & BSE: 532234; NSE: NATIONALUM \\
\hline DMU4 & Manganese Ore India & State-owned enterprise & Manganese ore & BSE: 533286; NSE: MOIL \\
\hline DMU5 & Oil and Natural Gas Corporation & Public sector rise & Mining and oil & BSE: 500312; NSE: ONGC \\
\hline DMU6 & National Mineral Development & State-owned enterprise & Minerals and meta & BSE: 526371; NSE: NMDC \\
\hline DMU7 & Sterlite Industries & Public company & Metal and mining & BSE: 500900; NYSE: SLT \\
\hline DMU8 & Hindalco Industries & Public company & Mining and metals & BSE: 500440; NSE: HINDALCO \\
\hline DMU9 & Hindustan Zinc Limited & Public company & Mining and smelting & BSE: 500188; NSE: HINDZINC \\
\hline DMU10 & Sesa Sterlite Limited & Public limited & & BSE: 500295; NSE: SESAGOA \\
\hline \multicolumn{5}{|c|}{ Section 2: Companies listed on the website of Money Control } \\
\hline DMU11 & Gujarat Mineral Development & State-owned enterprise & Mining and smelting & BSE: 532181; NSE: GMDCLTD \\
\hline DMU12 & Rohit Ferro Tech & Public company & Mining and minerals & BSE: 532731; NSE: ROHITFERRO \\
\hline DMU13 & Indian Metals \& Ferro Alloys & Public company & Mining and minerals & BSE: 533047; NSE: IMFA \\
\hline DMU14 & Maithan Alloys & Public company & Mining and minerals & BSE: 590078; NSE: MAITHANALL \\
\hline DMU15 & Impex Ferro Tech & Public company & Mining and minerals & BSE: 532614; NSE: IMPEXFERRO \\
\hline DMU16 & Ferro Alloys Corporation & Public company & Mining and minerals & BSE: 500141; NSE: FERROALLOY \\
\hline DMU17 & Coal India & State-owned enterprise & Mining and minerals & BSE: 533278; NSE: COALINDIA \\
\hline DMU18 & 20 Microns & Public company & Mining and minerals & BSE: 533022; NSE: 20 MICRONS \\
\hline DMU19 & Facor Alloys & Public company & Mining and minerals & BSE: 532656; NSE: FACORALLOY \\
\hline DMU20 & Associated Stone Industries & Public company & Mining and minerals & BSE: 502015; NSE: ASOCSTONE \\
\hline DMU21 & Sandur Manganese and Iron Ores & Public company & Mining and minerals & BSE: 504918; NSE: SANDUR \\
\hline DMU22 & Nagpur Power Industries & Public company & Mining and minerals & BSE: 532362; NSE: NAGPUR \\
\hline DMU23 & Resurgere Mines and Minerals & State-owned enterprise & Mining and minerals & BSE: 533017; NSE: RMMIL \\
\hline
\end{tabular}

TABLE 2: Financial results of Indian mining companies in 2014 (Rs. million; except EPS).

\begin{tabular}{|c|c|c|c|c|c|}
\hline DMUs & Expenditure (I) & Equity capital (I) & Net sales $(\mathrm{O})$ & Net profit $(\mathrm{O})$ & EPS $(\mathrm{O})$ \\
\hline DMU1 & $(11,509.50)$ & $4,626.10$ & $14,888.80$ & $2,864.20$ & 3.10 \\
\hline DMU2 & $(44,371.50)$ & $3,964.70$ & $120,582.00$ & $64,200.80$ & 16.19 \\
\hline DMU3 & $(63,713.80)$ & $12,886.20$ & $67,808.50$ & $6,423.50$ & 2.49 \\
\hline DMU4 & $(45,283.10)$ & $16,777.10$ & $59,672.30$ & $15,018.80$ & 8.95 \\
\hline DMU5 & $(44,371.50)$ & $3,964.70$ & $120,582.00$ & $64,200.80$ & 16.19 \\
\hline DMU6 & $(581,698.70)$ & $42,777.60$ & $838,889.30$ & $220,948.10$ & 25.83 \\
\hline DMU7 & $(183,682.30)$ & $3,361.20$ & $189,210.30$ & $15,772.70$ & 4.69 \\
\hline DMU8 & $(261,823.40)$ & $2,064.80$ & $278,509.30$ & $14,133.30$ & 7.09 \\
\hline DMU9 & $(74,591.10)$ & $8,450.60$ & $136,360.40$ & $69,046.20$ & 16.34 \\
\hline DMU10 & $(277,294.00)$ & $2,965.00$ & $285,365.30$ & $10,760.90$ & 3.67 \\
\hline DMU11 & $7,974.50$ & 636.00 & $12,896.70$ & $4,391.30$ & 13.81 \\
\hline DMU12 & $25,934.50$ & $1,137.80$ & $25,503.00$ & $(2,284.90)$ & $(20.08)$ \\
\hline DMU13 & $11,682.10$ & 259.80 & $12,433.40$ & 391.20 & 15.06 \\
\hline DMU14 & $7,840.30$ & 145.60 & $9,551.10$ & 113.10 & 7.83 \\
\hline DMU15 & $7,341.60$ & 816.00 & $6,875.00$ & $(548.60)$ & $(7.47)$ \\
\hline DMU16 & $5,947.70$ & 185.30 & $6,326.30$ & 313.60 & 1.69 \\
\hline DMU17 & $7,250.90$ & $63,163.60$ & $3,142.50$ & $150,085.40$ & 23.76 \\
\hline DMU18 & $2,773.80$ & 169.10 & $2,902.30$ & 1.30 & 0.04 \\
\hline DMU19 & $2,734.80$ & 195.50 & $2,401.10$ & $(282.60)$ & $(1.42)$ \\
\hline DMU20 & $1,121.40$ & 66.30 & $1,307.40$ & 100.70 & 7.60 \\
\hline DMU21 & $2,575.40$ & 87.50 & $2,959.10$ & 383.70 & 43.85 \\
\hline DMU22 & 38.20 & 131.00 & 15.40 & $(8.40)$ & $(0.64)$ \\
\hline DMU23 & 370.70 & $1,988.70$ & 0.70 & $(588.40)$ & $(2.96)$ \\
\hline
\end{tabular}


from the websites of Bombay Stock Exchange and Money Control. Collected data are derived as two classes: inputs and outputs. Data inputs consist of the capital expenditure and equity capital indices; and the outputs consist of the indices of net sale or income from operations, net profit, and basic EPS after extraordinary items.

In last sections, we have mentioned information about introduction, motivation, selection of companies, and selection attributes of these firms. After the setting stages, we go to the analysis stage at which research models are applied. In performing evaluation by ranking, super SBM is employed. $\operatorname{GM}(1,1)$ is used for forecasting the parameters that can then be used for future estimated ranking among mining companies. On the other side, Malmquist nonradial and radial models are applied to demonstrate performance evaluation. However, we need to see whether significant differences exist between these models and then Wilcoxon can handle this task. Again, $\operatorname{GM}(1,1)$ in the previous section is utilized to see future trends. Finally, we could easily analyze the efficiency change based MPI.

3.2. Models of Data Envelopment Analysis (DEA). The DEA pioneered by Charnes et al. [14] and developed by Banker et al. [15] and Fare et al. [16] is a mathematical programming approach which characterises the relationship among multiple inputs and multiple outputs by envelopment of the observed data to determine the best practice frontier for production. DEA involves the use of linear programming methods to construct a nonparametric piecewise surface or frontier over the data. Efficiency measures are then calculated relative to this surface which can be perceived as the production possibility frontier.

The Malmquist index evaluates the efficiency change of a DMU between two time periods. It is defined as the product of "catch-up" and "frontier-shift" terms. The catch-up term is related to the degree of efforts that the DMU attained for improving its efficiency, while the frontier-shift term reflects the change in the efficient frontiers surrounding the DMU between the two time periods 1 and 2 . We denote $\mathrm{DMU}_{0}$ at the time periods 1 and 2 by $\left(x_{0}^{1}, y_{0}^{1}\right)$ and $\left(x_{0}^{2}, y_{0}^{2}\right)$, respectively. We employ the following notation for the efficiency score of DMU $\left(x_{0}, y_{0}\right)^{t_{1}}$ measured by the frontier technology $t_{2}$. $\delta^{t_{2}}\left(\left(x_{0}, y_{0}\right)^{t_{1}}\right)\left(t_{1}=1,2\right.$ and $\left.t_{2}=1,2\right)$.

Then, the catch-up effect is measured by the following formula:

$$
C=\frac{\delta^{2}\left(\left(x_{0}, y_{0}\right)^{2}\right)}{\delta^{1}\left(\left(x_{0}, y_{0}\right)^{1}\right)}
$$

The frontier-shift effect is described as

$$
F=\left[\frac{\delta^{1}\left(\left(x_{0}, y_{0}\right)^{1}\right)}{\delta^{2}\left(\left(x_{0}, y_{0}\right)^{1}\right)} \times \frac{\delta^{1}\left(\left(x_{0}, y_{0}\right)^{2}\right)}{\delta^{2}\left(\left(x_{0}, y_{0}\right)^{2}\right)}\right]^{1 / 2}
$$

Malmquist index (MI) is the product of $C$ and $F$; that is, Malmquist index $=($ catch-up $) \times($ frontier-shift $)$ or $\mathrm{MI}=C *$ F or

$$
\mathrm{MI}=\left[\frac{\delta^{1}\left(\left(x_{0}, y_{0}\right)^{2}\right)}{\delta^{1}\left(\left(x_{0}, y_{0}\right)^{1}\right)} \times \frac{\delta^{2}\left(\left(x_{0}, y_{0}\right)^{2}\right)}{\delta^{2}\left(\left(x_{0}, y_{0}\right)^{1}\right)}\right]^{1 / 2} .
$$

$(C) ;(F) ;(\mathrm{MI})>1$ indicates progress in relative efficiency from period 1 to period 2, while $(C) ;(F) ;(\mathrm{MI})=1$ and $(C) ;(F)$; $(\mathrm{MI})<1$ indicate the status quo and regress in efficiency, respectively.

(Note that DEA efficiency is considered a distance measure in the literature as it reflects the efficiency of converting inputs to outputs [16]).

We can develop the output-oriented $M I$ as well by means of the output-oriented radial DEA models. The outputoriented models take all output slacks into account but no input slacks. This is explained below-within score in outputorientation $(\mathrm{O}-\mathrm{V})$ :

$$
\begin{gathered}
\delta^{s}\left(\left(x_{0}, y_{0}\right)^{s}\right)=\min _{\theta, \lambda} \theta \\
\text { subject to } x_{0}^{s} \geq X^{s} \lambda \\
\left(\frac{1}{\theta}\right) y_{0}^{s} \leq Y^{s} \lambda \\
L \leq e \lambda \leq U \\
\lambda \geq 0 .
\end{gathered}
$$

Intertemporal score in output-orientation $(\mathrm{O}-\mathrm{V})$ :

$$
\begin{gathered}
\delta^{s}\left(\left(x_{0}, y_{0}\right)^{t}\right)=\min _{\theta, \lambda} \theta \\
\text { subject to } x_{0}^{t} \geq X^{s} \lambda \\
\left(\frac{1}{\theta}\right) y_{0}^{t} \leq Y^{s} \lambda \\
L \leq e \lambda \leq U \\
\lambda \geq 0 .
\end{gathered}
$$

The radial approaches suffer from one general problem, that is, the neglect of slacks. In an effort to overcome this problem, Tone $[17,18]$ has developed the nonradial measures of efficiency and super-efficiency slack-based measure (SBM) and super SBM. Using these measures, we develop here the nonradial and slacks-based MI. In the output-oriented case, we solve the following LPs.

SBM-O

$$
\begin{gathered}
\delta^{t}\left(\left(x_{0}, y_{0}\right)^{s}\right)=\frac{\min _{\lambda, s^{+}} 1}{\left(1+\left((1 / q) \sum_{i=1}^{q} s_{i}^{+}\right) / y_{i 0}^{s}\right)} \\
\text { subject to } x_{0}^{s} \geq X^{t} \lambda \\
y_{0}^{s}=Y^{t} \lambda-s^{+} \\
L \leq e \lambda \leq U \\
\lambda \geq 0, \quad s^{+} \geq 0,
\end{gathered}
$$

where the vector $s^{+} \in R^{q}$ denotes the output-slacks. 
TABLE 3: Forecasted values of outputs of all DMUs from 2015 to 2018.

\begin{tabular}{|c|c|c|c|c|c|c|c|c|c|c|c|c|}
\hline \multirow{3}{*}{ DMUs } & \multicolumn{12}{|c|}{ Outputs (Rs. millions, except EPS) } \\
\hline & \multicolumn{4}{|c|}{ (O) Net sale } & \multicolumn{4}{|c|}{ (O) Net profit } & \multicolumn{4}{|c|}{ (O) EPS } \\
\hline & ' 15 & '16 & ' 17 & ' 18 & ' 15 & ‘16 & '17 & ' 18 & ' 15 & '16 & $' 17$ & ‘ 18 \\
\hline DMU1 & $15,846.62$ & $16,855.90$ & $17,929.47$ & $19,071.42$ & 3498.10 & 3736.30 & 3990.72 & 4262.47 & 3.78 & 4.04 & 4.32 & 4.62 \\
\hline DMU2 & $117,408.21$ & $119,022.55$ & $120,659.08$ & $122,318.12$ & 63524.04 & 62444.81 & 61383.92 & 60341.05 & 16.02 & 15.75 & 15.48 & 15.22 \\
\hline DMU3 & $72,203.19$ & $74,912.73$ & $77,723.95$ & $80,640.67$ & 4512.24 & 3659.75 & 2968.31 & 2407.51 & 1.77 & 1.44 & 1.17 & 0.95 \\
\hline DMU4 & $69,654.52$ & $79,310.72$ & $90,305.56$ & $102,824.62$ & 15882.79 & 16630.55 & 17413.51 & 18233.34 & 9.46 & 9.91 & 10.37 & 10.86 \\
\hline DMU5 & $117,408.21$ & $119,022.55$ & $120,659.08$ & $122,318.12$ & 63524.04 & 62444.81 & 61383.92 & 60341.05 & 16.02 & 15.75 & 15.48 & 15.22 \\
\hline MU6 & $913,629.42$ & $973,669.79$ & $1,037,655.7$ & $1,105,846.71$ & 230656.89 & 236100.11 & 241671.79 & 247374.95 & 26.97 & 27.60 & 28.26 & 28.93 \\
\hline DMU7 & $219,108.91$ & $247,255.18$ & $279,017.07$ & $314,859.02$ & 20323.30 & 23922.28 & 28158.58 & 33145.07 & 2.46 & 1.77 & 1.27 & 0.92 \\
\hline MU8 & $290,498.75$ & $303,415.46$ & $316,906.49$ & $330,997.39$ & 13089.95 & 11400.75 & 9929.53 & 8648.16 & 6.63 & 5.72 & 4.94 & 4.26 \\
\hline DMU9 & $152,381.10$ & $168,446.89$ & $186,206.52$ & $205,838.57$ & 80780.25 & 90989.33 & 102488.64 & 115441.24 & 19.12 & 21.53 & 24.25 & 27.31 \\
\hline DMU10 & 75104.60 & 65134.50 & 21879.20 & 285365.30 & 1917.26 & 942.61 & 463.43 & 227.84 & 1.09 & 0.45 & 0.18 & 0.08 \\
\hline MU11 & $14,284.14$ & $13,997.80$ & $13,717.21$ & $13,442.23$ & 5480.60 & 5805.70 & 6150.09 & 6514.90 & 17.23 & 18.25 & 19.33 & 20.48 \\
\hline DMU12 & $33,547.14$ & $42,602.86$ & $54,103.08$ & $68,707.68$ & 324.70 & 440.30 & 395.90 & 291.70 & -0.05 & -0.05 & 6.82 & 3.21 \\
\hline DMU13 & $13,138.04$ & $13,776.97$ & $14,446.98$ & $15,149.56$ & 151.86 & 85.20 & 47.80 & 26.81 & 5.95 & 3.37 & 1.90 & 1.08 \\
\hline DMU14 & $11,696.07$ & $13,749.55$ & $16,163.56$ & $19,001.40$ & 140.57 & 93.42 & 62.08 & 41.26 & 9.86 & 6.58 & 4.39 & 2.93 \\
\hline DMU15 & $7,098.15$ & $7,554.20$ & $8,039.54$ & $8,556.07$ & 57.10 & 68.00 & 35.90 & 39.70 & 1.22 & 1.36 & 0.69 & 0.59 \\
\hline DMU16 & $6,603.83$ & $7,228.25$ & $7,911.72$ & $8,659.81$ & 269.88 & 289.35 & 310.22 & 332.60 & 1.46 & 1.58 & 1.70 & 1.82 \\
\hline DMU17 & $2,952.48$ & $2,695.00$ & $2,459.98$ & $2,245.45$ & 207114.37 & 295181.64 & 420696.07 & 599580.59 & 32.84 & 46.74 & 66.52 & 94.67 \\
\hline DMU18 & $3,121.05$ & $3,327.60$ & $3,547.81$ & $3,782.60$ & 20.85 & 15.01 & 10.81 & 7.78 & 1.10 & 0.74 & 0.50 & 0.34 \\
\hline DMU19 & $1,780.98$ & $1,451.45$ & $1,182.90$ & 964.03 & 140.30 & 328.50 & 71.20 & 8.00 & -1.42 & 0.52 & 1.69 & 0.36 \\
\hline DMU20 & $1,356.48$ & $1,266.35$ & $1,182.21$ & $1,103.66$ & 107.47 & 106.31 & 105.15 & 104.01 & 8.11 & 8.02 & 7.93 & 7.84 \\
\hline DMU21 & $1,931.12$ & $1,758.03$ & $1,600.44$ & $1,456.99$ & 102.21 & 62.37 & 38.06 & 23.22 & 11.63 & 7.09 & 4.32 & 2.63 \\
\hline DMU22 & 16.10 & 15.40 & 110.10 & 18.30 & 3.95 & 2.26 & 1.29 & 0.74 & 0.30 & 0.17 & 4.11 & 3.35 \\
\hline DMU23 & 6.23 & 1.14 & 0.21 & 0.04 & -588.40 & -770.00 & 43.90 & -588.40 & -7.79 & -13.57 & 7.65 & -0.03 \\
\hline
\end{tabular}

Source: calculated by researchers.

Super SBM-O

$$
\begin{gathered}
\delta^{t}\left(\left(x_{0}, y_{0}\right)^{s}\right)=\frac{\min _{\lambda, s^{+}} 1}{\left(1-\left((1 / q) \sum_{i=1}^{q} s_{i}^{+}\right) / y_{i 0}^{t}\right)} \\
\text { subject to } x_{0}^{s} \geq X^{t} \lambda \\
y_{0}^{s} \leq Y^{t} \lambda+s^{+} \\
L \leq e \lambda \leq U \\
\lambda \geq 0, \quad s^{+} \geq 0 .
\end{gathered}
$$

3.3. Grey Forecasting Model. The researchers use $\operatorname{GM}(1,1)$ model to predict the realistic input/output factors for the next 4 years (2015 to 2018). In this section, the study takes company DMU1 as an example to understand how to compute in GM(1, 1) model in the period 2010-2014. We also take the net sales of DMU1 as an example to explain calculation procedure, and other variables are calculated in the same way. The procedure is carried out step by step as follows.

First, the researchers use the $\operatorname{GM}(1,1)$ model to try to forecast the variance of primitive series.

First, create the primitive series:

$X^{(0)}=(13,045.20 ; 11,465.20 ; 14,875.50 ; 13,231.40 ;$ $14,888.80)$.
Second, perform the accumulated generating operation (AGO):

$X^{(1)}=(13,045.20 ; 25,401.40 ; 40,276.90 ; 53,508.30$; $68,397.10)$

$X^{(1)}=x^{(0)}(1)=13,045.20$

$x^{(1)}(2)=x^{(0)}(1)+x^{(0)}(2)=25,401.40$

$x^{(1)}(3)=x^{(0)}(1)+x^{(0)}(2)+x^{(0)}(3)=40,276.90$

$x^{(1)}(4)=x^{(0)}(1)+x^{(0)}(2)+x^{(0)}(3)+x^{(0)}(4)=53,508.30$

$x^{(1)}(5)=x^{(0)}(1)+x^{(0)}(2)+x^{(0)}(3)+x^{(0)}(4)+x^{(0)}(5)$

$$
=68,397.10 \text {. }
$$

Third, create the different equations of $\operatorname{GM}(1,1)$.

To find $Z$ series, the following steps can be caculated to obtain the results:

$$
\begin{aligned}
& z^{(1)}(2)=(1 / 2)(13,045.20+25,401.40)=38446.6 \\
& z^{(1)}(3)=(1 / 2)(25,401.40+40,276.90)=65,678.3 \\
& z^{(1)}(4)=(1 / 2)(40,276.90+53,508.30)=93,785.2 \\
& z^{(1)}(5)=(1 / 2)(53,508.30+68,397.10)=121,905.4 .
\end{aligned}
$$

Fourth, solve equations. 
TABLE 4: Average MAPE of DMUs.

\begin{tabular}{lc}
\hline DMUs & Average MAPE \\
\hline DMU1 & $10.27 \%$ \\
DMU2 & $5.42 \%$ \\
DMU3 & $6.06 \%$ \\
DMU4 & $1.87 \%$ \\
DMU5 & $5.42 \%$ \\
DMU6 & $5.61 \%$ \\
DMU7 & $10.50 \%$ \\
DMU8 & $4.42 \%$ \\
DMU9 & $3.14 \%$ \\
DMU10 & $15.55 \%$ \\
DMU11 & $11.40 \%$ \\
DMU12 & $7.33 \%$ \\
DMU13 & $12.54 \%$ \\
DMU14 & $14.65 \%$ \\
DMU15 & $8.64 \%$ \\
DMU16 & $5.89 \%$ \\
DMU17 & $5.56 \%$ \\
DMU18 & $20.18 \%$ \\
DMU19 & $10.54 \%$ \\
DMU20 & $9.15 \%$ \\
DMU21 & $13.40 \%$ \\
DMU22 & $8.06 \%$ \\
DMU23 & $32.48 \%$ \\
\hline & \\
\hline
\end{tabular}

TABLE 5: Pearson correlation coefficient.

\begin{tabular}{lc}
\hline Correlation coefficient & Degree of correlation \\
\hline$>0.8$ & Very high \\
$0.6-0.8$ & High \\
$0.4-0.6$ & Medium \\
$0.2-0.4$ & Low \\
$<0.2$ & Very low \\
\hline
\end{tabular}

To find $a$ and $b$, the primitive series values are substituted into the Grey differential equation to obtain

$$
\begin{array}{r}
11,465.20+a \times 38446.6=b \\
14,875.50+a \times 65,678.3=b \\
13,231.40+a \times 93,785.2=b \\
14,888.80+a \times 121,905.4=b .
\end{array}
$$

Convert the linear equations into the form of a matrix.

Let

$$
B=\left[\begin{array}{c}
-38446.6 \\
-65,678.3 \\
-93,785.2 \\
-121,905.4
\end{array}\right], \quad \widehat{\theta}=\left[\begin{array}{l}
a \\
b
\end{array}\right]
$$

$$
y_{N}=\left[\begin{array}{l}
11,465.20 \\
14,875.50 \\
13,231.40 \\
14,888.80
\end{array}\right]
$$

And then use the least square method to find $a$ and $b$ :

$$
\left[\begin{array}{l}
a \\
b
\end{array}\right]=\widehat{\theta}=\left(B^{T} B\right)^{-1} B^{T} y_{N}=\left[\begin{array}{c}
-0.0617 \\
11194.99
\end{array}\right] .
$$

Use the two coefficients $a$ and $b$ to generate the whitening equation of the differential equation:

$$
\frac{d x^{(1)}}{d t}-0.0617 \times x^{(1)}=11194.99 .
$$

Find the prediction model from

$$
\begin{aligned}
X^{(1)}(k+1) & =\left(X^{(0)}(1)-\frac{b}{a}\right) e^{-a k}+\frac{b}{a} \\
x^{(1)}(k+1) & =\left(13045.2-\frac{11194.99}{-0.0617}\right) e^{0.0617 k}+\frac{11194.99}{-0.0617} \\
& =(194487.5) e^{0.0696 k}-181442.3 .
\end{aligned}
$$

Substitute different values of $k$ into the equation:

$$
\begin{aligned}
& k=0 X^{(1)}(1)=13045.20 \\
& k=1 X^{(1)}(2)=25423.89 \\
& k=2 X^{(1)}(3)=38591.00 \\
& k=3 X^{(1)}(4)=52596.73 \\
& k=4 X^{(1)}(5)=67494.50 \\
& k=5 X^{(1)}(6)=83341.12 \\
& k=6 X^{(1)}(7)=100197.02 \\
& k=7 X^{(1)}(8)=118126.49 \\
& k=8 X^{(1)}(9)=137197.91 .
\end{aligned}
$$

Derive the predicted value of the original series according to the accumulated generating operation and obtain

$$
\begin{aligned}
& \widehat{x}^{(0)}(1)=x^{(1)}(1)=13045.2 \text {-for the year } 2010 \\
& \widehat{x}^{(0)}(2)=x^{(1)}(2)-x^{(1)}(1)=12,378.69 \text {-forecasted for } \\
& 2011 \\
& \widehat{x}^{(0)}(3)=x^{(1)}(3)-x^{(1)}(2)=13,167.11 \text {-forecasted for } \\
& 2012 \\
& \widehat{x}^{(0)}(4)=x^{(1)}(4)-x^{(1)}(3)=14,005.73 \text {-forecasted for } \\
& 2013 \\
& \widehat{x}^{(0)}(5)=x^{(1)}(5)-x^{(1)}(4)=17,897.77 \text {-forecasted for } \\
& 2014 \\
& \widehat{x}^{(0)}(6)=x^{(1)}(6)-x^{(1)}(5)=15,846.62 \text {-forecasted for } \\
& 2015 \\
& \widehat{x}^{(0)}(7)=x^{(1)}(7)-x^{(1)}(6)=16,855.90 \text {-forecasted for } \\
& 2016
\end{aligned}
$$


TABLE 6: Correlation coefficient (2014).

\begin{tabular}{lccccccc}
\hline & Staff cost & Energy purchase & Other expenses & Equity capital & Net income & Net profit & Basic EPS \\
\hline Staff cost & 1 & 0.380873213 & 0.98075502 & 0.627931207 & 0.221718204 & 1 & 0.380873213 \\
Energy purchase & 0.380873213 & 1 & 0.418084532 & 0.844263775 & 0.39597191 & 0.380873213 & 1 \\
Other expenses & 0.98075502 & 0.418084532 & 1 & 0.718349623 & 0.284462435 & 0.98075502 & 0.418084532 \\
Equity capital & 0.627931207 & 0.844263775 & 0.718349623 & 1 & 0.501068342 & 0.627931207 & 0.844263775 \\
Net income & 0.221718204 & 0.39597191 & 0.284462435 & 0.501068342 & 1 & 0.221718204 & 0.39597191 \\
Net profit & 1 & 0.380873213 & 0.98075502 & 0.627931207 & 0.221718204 & 1 & 0.380873213 \\
Basic EPS & 0.380873213 & 1 & 0.418084532 & 0.844263775 & 0.39597191 & 0.380873213 & 1 \\
\hline
\end{tabular}

$$
\begin{aligned}
& \widehat{x}^{(0)}(8)=x^{(1)}(8)-x^{(1)}(7)=17,929.47 \text {-forecasted for } \\
& 2017 \\
& \widehat{x}^{(0)}(9)=x^{(1)}(9)-x^{(1)}(8)=19,071.42 \text {-forecasted for } \\
& 2018 .
\end{aligned}
$$

Similarly to the above computation process, the study could get the forecasting results of all DMUs from 2015 and 2018; the detailed numbers are shown in Tables 3 and 4, respectively.

3.4. Forecasting Accuracy. The mean absolute percentage error (MAPE) is a measure of accuracy of a method for constructing fitted time series values in statistics, specifically in trend estimation [19-21]. The MAPE measures the size of the error in percentage terms. Many previous studies focus primarily on the MAPE when assessing forecast accuracy. It is calculated as the average of the unsigned percentage error as follows:

$$
\text { MAPE }=\frac{1}{n} \sum \frac{\mid \text { Actual }- \text { Forecast } \mid}{\text { Actual }} \times 100
$$

$n$ is forecasting number of steps.

The parameters of MAPE stating out the forecasting ability are as follows:

$$
\begin{aligned}
& \text { MAPE < 10\% "Excellent" } \\
& 10 \%<\text { MAPE < } 20 \% \text { "Good" } \\
& 20 \%<\text { MAPE < 50\% "Reasonable" } \\
& \text { MAPE > 50\% "Poor." }
\end{aligned}
$$

\section{Data Analysis and Results}

4.1. Forecasting Results. Forecasting results from 2015 to 2018 of 23 Indian mining companies were shown in Table 3.

The authors employed MAPE to test the forecasting accuracy of 23 Indian mining companies and MAPE is a very important tool to solve the mathematical concerns about the forecasting method. As shown in Table 4, average MAPE of each DMU is ranked from $3 \%$ to $10 \%$. In particular, the average MAPE of total 23 DMUs is $9.92 \%$ which is below $10 \%$; thus, it can conclude that the $\operatorname{GM}(1,1)$ model provides highly accurate prediction for the case of this research.

4.2. Pearson Correlation. To apply DEA model, the authors have to make sure that the relationship between input and
TABLE 7: Summary of super SBM results for 2014.

Number of DMUs in data: 23

Number of DMUs with inappropriate data: 0

Number of evaluated DMUs: 23

Average of scores: 0.6230249

Number of efficient DMUs: 13

Number of inefficient DMUs: 10

Number of over iteration DMUs: 0

output factors is correlated, which means if the input quantity increases, the output quantity could not decrease under the same condition [22]. Firstly, a simple correlation test, Pearson correlation, to measures the degree of association between two variables is conducted. Higher correlation coefficient means closer relation between two variables, while lower correlation coefficient means that they are less correlated.

The interpretation of the correlation coefficient is explained in more detail as follows. The correlation coefficient is always between -1 and +1 . The closer the correlation is to \pm 1 , the closer it is to a perfect linear relationship. Its general meaning was shown in Table 5.

In the empirical study, the results in Table 6 indicate that the correlation complies well with the prerequisite condition of the DEA model because their correlation coefficient shows strong positive associations. Therefore, these positive correlations also demonstrate very clearly the fact that the researcher's choice of input and output variables at the beginning is appropriate. Obviously, none of variables removal is necessary. From these results, we can justify the reason for why we use these indicators for DEA methodologies. The correlation is also very significant which will affect the performance.

4.3. Performance Rankings of Super SBM. Table 7 shows summary of super SBM results for data of the year 2014. Data are set at value Returns to Scale = Variable (Sum of Lambda = 1). The total number of DMUs is 23 with none of inappropriate data. The number of efficient DMUs is 13, while the result reveals 10 DUMs that work inefficiently. The results demonstrated that SBM has the ability to distinguish all DMUs with significant differences on their scoring. The results also revealed that a large number of inefficient mining companies still exist. 
TABLE 8: Past-present period scores and rankings of Indian mining companies.

\begin{tabular}{|c|c|c|c|c|c|c|c|c|c|c|}
\hline \multirow{2}{*}{$\frac{\text { Year }}{\text { DMUs }}$} & \multicolumn{2}{|c|}{2010} & \multicolumn{2}{|l|}{2011} & \multicolumn{2}{|l|}{2012} & \multicolumn{2}{|l|}{2013} & \multicolumn{2}{|l|}{2014} \\
\hline & Score & Rank & Score & Rank & Score & Rank & Score & Rank & Score & Rank \\
\hline DMU1 & 0.08222255 & 20 & 0.0656456541 & 18 & 0.170071799 & 17 & 0.17558929 & 15 & 0.138931313 & 16 \\
\hline DMU2 & 1 & 8 & 1 & 6 & 1 & 7 & 1 & 6 & 1 & 6 \\
\hline DMU3 & 0.2055158 & 15 & 0.113620718 & 16 & 0.162615278 & 18 & 0.134712868 & 16 & 0.125793692 & 17 \\
\hline DMU4 & 0.19229379 & 16 & 0.198593163 & 15 & 0.291067259 & 15 & 0.34429635 & 14 & 0.318260742 & 14 \\
\hline DMU5 & 1 & 8 & 1 & 6 & 1 & 7 & 1 & 6 & 1 & 6 \\
\hline DMU6 & 2.16770264 & 1 & 2.033090027 & 1 & 2.80326237 & 1 & 2.31536708 & 1 & 1.95872746 & 1 \\
\hline DMU7 & 0.77740861 & 12 & 0.366271981 & 13 & 0.331701432 & 14 & 0.451008567 & 12 & 0.410027591 & 13 \\
\hline DMU8 & 1.15413633 & 6 & 1.199295331 & 5 & 1.272546625 & 3 & 1.289155822 & 4 & 1.161877176 & 4 \\
\hline DMU9 & 1.42647404 & 3 & 0.455163255 & 10 & 0.672443382 & 11 & 0.917292682 & 10 & 0.882773643 & 10 \\
\hline DMU10 & 1.46305544 & 2 & 1.461774497 & 3 & 1.147627203 & 5 & 0.084511232 & 18 & 0.599494462 & 11 \\
\hline DMU11 & 0.45409773 & 13 & 0.243722044 & 14 & 0.568035889 & 12 & 0.673623254 & 11 & 0.475303705 & 12 \\
\hline DMU12 & 0.12372762 & 19 & 0.077112542 & 17 & 0.0752215685 & 19 & 0.042416986 & 19 & 0.000171154 & 23 \\
\hline DMU13 & 0.23899823 & 14 & 0.418336879 & 11 & 0.407331963 & 13 & 0.381797764 & 13 & 0.270659073 & 15 \\
\hline DMU14 & 1.09447397 & 7 & 0.369363507 & 12 & 1.238128139 & 4 & 1.022411301 & 5 & 1.018807964 & 5 \\
\hline DMU15 & 0.02661588 & 22 & 0.0154215465 & 22 & 0.009125436 & 23 & 0.010363164 & 21 & 0.000335555 & 22 \\
\hline DMU16 & 0.01421234 & 23 & 0.0492145623 & 20 & 0.0262563212 & 21 & 0.087653698 & 17 & 0.091590783 & 18 \\
\hline DMU17 & 1.34986652 & 4 & 1.323199209 & 4 & 1.402620489 & 2 & 1.409316421 & 2 & 1.457257143 & 2 \\
\hline DMU18 & 0.169931707 & 17 & 0.0656414141 & 19 & 0.176270834 & 16 & 0.036263254 & 20 & 0.001525555 & 19 \\
\hline DMU19 & 0.05345621 & 21 & 0.042986456 & 21 & 0.039523654 & 20 & 0.002632693 & 22 & 0.001275366 & 20 \\
\hline DMU20 & 1 & 8 & 0.99985281 & 9 & 1 & 7 & 1 & 6 & 1 & 6 \\
\hline DMU21 & 1.173117286 & 5 & 1.503902073 & 2 & 1.053500985 & 6 & 1.335737125 & 3 & 1.417097825 & 3 \\
\hline DMU22 & 1 & 8 & 1 & 6 & 1 & 7 & 1 & 6 & 0.999033846 & 9 \\
\hline DMU23 & 0.159980331 & 18 & 0.0090814569 & 23 & 0.016914788 & 22 & 0.0019455655 & 23 & 0.000641568 & 21 \\
\hline
\end{tabular}

TABLE 9: Future scores and rankings of Indian mining companies.

\begin{tabular}{|c|c|c|c|c|c|c|c|c|}
\hline \multirow{2}{*}{$\begin{array}{l}\text { Year } \\
\text { DMUs }\end{array}$} & \multicolumn{2}{|c|}{2015} & \multicolumn{2}{|c|}{2016} & \multicolumn{2}{|c|}{2017} & \multicolumn{2}{|c|}{2018} \\
\hline & Score & Rank & Score & Rank & Score & Rank & Score & Rank \\
\hline DMU1 & 0.229972135 & 15 & 0.213906606 & 17 & 0.194115582 & 16 & 0.16885867 & 15 \\
\hline DMU2 & 1 & 10 & 1 & 8 & 1 & 7 & 1 & 8 \\
\hline DMU3 & 0.091149209 & 18 & 0.065455222 & 20 & 0.04547795 & 20 & 0.058719106 & 18 \\
\hline DMU4 & 0.310139476 & 14 & 0.283446393 & 15 & 0.24829818 & 14 & 0.207261952 & 14 \\
\hline DMU5 & 1 & 10 & 1 & 8 & 1 & 7 & 1 & 8 \\
\hline DMU6 & 1.706458481 & 2 & 1.5043684 & 2 & 1.405519183 & 2 & 1.376640904 & 2 \\
\hline DMU7 & 1.11595166 & 5 & 0.366177711 & 13 & 0.308945554 & 12 & 1.036782468 & 7 \\
\hline DMU8 & 1.15220434 & 3 & 1.223512939 & 3 & 1.205320998 & 5 & 1.164404419 & 5 \\
\hline DMU9 & 1.04140483 & 8 & 1.114485601 & 5 & 1.206617814 & 4 & 1.288194472 & 4 \\
\hline DMU10 & 1.133620135 & 4 & 1.076409889 & 6 & 0.02375703 & 21 & 0.012712324 & 21 \\
\hline DMU11 & 1.107899893 & 6 & 1.20380724 & 4 & 1.263214488 & 3 & 1.293168383 & 3 \\
\hline DMU12 & 0.047504052 & 20 & 0.025649868 & 22 & 0.072401558 & 18 & 0.058719106 & 17 \\
\hline DMU13 & 0.131526256 & 17 & 0.085196414 & 19 & 0.050240732 & 19 & 0.030354919 & 19 \\
\hline DMU14 & 1.02542509 & 9 & 1.037274478 & 7 & 1.062498136 & 6 & 1.092104258 & 6 \\
\hline DMU15 & 0.02226702 & 22 & 0.02306484 & 23 & 0.01248637 & 23 & 0.011367331 & 23 \\
\hline DMU16 & 0.199700493 & 16 & 0.239275087 & 16 & 0.263227147 & 13 & 0.293008055 & 13 \\
\hline DMU17 & 1.934646173 & 1 & 2.120759681 & 1 & 2.286584498 & 1 & 2.429443651 & 1 \\
\hline DMU18 & 0.040603593 & 21 & 0.029652426 & 21 & 0.01865052 & 22 & 0.012372634 & 22 \\
\hline DMU19 & 0.059686158 & 19 & 0.12894573 & 18 & 0.118590775 & 17 & 0.014157442 & 20 \\
\hline DMU20 & 1 & 10 & 1 & 8 & 1 & 7 & 1 & 8 \\
\hline DMU21 & 1.098633465 & 7 & 0.320449656 & 14 & 0.206757982 & 15 & 0.131634947 & 16 \\
\hline DMU22 & 1 & 10 & 0.999085759 & 11 & 1 & 7 & 1 & 8 \\
\hline DMU23 & 0.01187598 & 23 & 0.997461493 & 12 & 1 & 7 & 0.997033889 & 12 \\
\hline
\end{tabular}


Table 8 shows the five-year data with efficiency scores and ranking of DMUs based on DEA-super SBM. This indicates that the ranking of the Indian mining industries is tending to change in a very slight manner on yearly basis. However, the majority of these companies are maintaining their "efficient" levels even after yearly changes on their financial nature.

Table 9 shows forecasting results for companies' future ranking by applying $\operatorname{GM}(1,1)$. In the future, obviously, these mining companies are keeping their performance and they just show slight changes between the efficiency scores. However, we can still see some of the companies are under " 1 " of efficiency, that is, inefficiency.

4.4. Performance Efficiency Evaluation: Malmquist Radial Model versus Malmquist Nonradial Model. Seiford and Zhu [23] stated that the performance efficiency evaluation is very essential to test the progress of development of an industry. The authors in this case used the two models: Malmquist Radial and Malmquist nonradial. Then, the results of Malmquist are shown in Table 10. Malmquist radial model has the average score of 0.992449 compared with 3.186667092 of Malmquist nonradial model.

In Table 11, the authors used Wilcoxon to test the differences. The authors, firstly, decide to formulate the null hypothesis as "There is no difference of performance efficiency evaluation between Malmquist radial and Malmquist nonradial models."

The results (shown in Table 11) indicate that the correlations between two pared samples at $(n=23$, correlation $=$ $-0.264, P=0.223, P<0.05)$, which means that there is significant difference between correlations of the two models mentioned.

Next, the results of Wilcoxon test (Table 12) show that $M=-2.39, \mathrm{SD}=5.59,95 \% \mathrm{CI}=-4.81 ; 2.42, t=-2.05, \mathrm{df}=$ $22, P=0.052$, in which $95 \%$ confidence interval of the difference goes through 0 and $P$ value $>0.05$. Thus, the authors can conclude that there is no significant difference between the two models: Malmquist radial and Malmquist nonradial.

Because of no significant difference between the Malmquist radial and Malmquist nonradial models, the authors decided to use one type of Malmquist models which is nonradial $\mathrm{O}-\mathrm{V}$ model, as it was mentioned above that the radial approaches suffer from one general problem, that is, the neglect of slacks. Avkiran [24] and Chen and Sherman [25] have developed the nonradial measures of efficiency and super-efficiency. Table 13 and Figure 1 show the efficiency change or what is named "catch-up" of the India mining industry over the year periods of time interval.

Figure 1 shows the efficiency change or what is named "catch-up" of the India mining industry. The efficiency changes are inconsistent because the activities of DMU financial management show its inconsistent nature over the years. Figure 1 also pointed out that wildly fluctuations of the changes exit among DMU19 (Facor Alloy), DMU15 (Impex Ferro), DMU12 (Rohit Ferro Tech), and DMU16 (Ferro Alloys Corporation), whereas the rest of Indian mining companies in this study have no big or very slight efficiency changes.

The technical or the frontier-shift changes of the companies over the period from 2010 to 2014 in the Indian mining
TABLE 10: The average indices of Malmquist radial and Malmquist nonradial models.

\begin{tabular}{lcc}
\hline DMUs & $\begin{array}{c}\text { Average of Malmquist } \\
\text { radial model }\end{array}$ & $\begin{array}{c}\text { Average Malmquist } \\
\text { nonradial model }\end{array}$ \\
\hline DMU1 & 1.133494181 & 1.787272636 \\
DMU2 & 1.151012585 & 1.078393423 \\
DMU3 & 0.952467408 & 0.392025795 \\
DMU4 & 1.076600714 & 1.090141392 \\
DMU5 & 1.151012585 & 1.078393423 \\
DMU6 & 0.803070747 & 0.802696168 \\
DMU7 & 0.922470548 & 0.446041138 \\
DMU8 & 1.173203288 & 1.048869372 \\
DMU9 & 0.713581338 & 0.714687685 \\
DMU10 & 0.868461435 & 0.58990751 \\
DMU11 & 1.074534927 & 1.245075457 \\
DMU12 & 0.907476297 & 6.041737971 \\
DMU13 & 1.165347005 & 0.918020595 \\
DMU14 & 1.014276704 & 0.969117286 \\
DMU15 & 0.842045652 & 25.50093872 \\
DMU16 & 1.197349339 & 8.304036297 \\
DMU17 & 2.506109416 & 2.060379686 \\
DMU18 & 0.948798068 & 0.011004036 \\
DMU19 & 0.832072153 & 16.49060082 \\
DMU20 & 0.904174513 & 0.969111616 \\
DMU21 & 1.269170129 & 1.359494943 \\
DMU22 & 0.209590622 & 0.382229953 \\
DMU23 & 0.01 & 0.013167199 \\
\hline Mean & $\mathbf{0 . 9 9 2 4 4 9}$ & 25.50093872 \\
\hline Max & 2.506109 & 0.011004036 \\
\hline Min & 0.01 & \\
\hline & 0.443929 & \\
\hline
\end{tabular}

TABLE 11: Paired samples correlations.

\begin{tabular}{llcc}
\hline & $N$ & Correlation & Sig. \\
\hline Nonradial and radial & 23 & -0.264 & 0.223 \\
\hline
\end{tabular}

industry are shown in Table 14 and Figure 2. Figure 2 shows that the tendency to change technical or innovative effect of most of the Indian mining companies is inconsistent. For example, DMU19 (Facor Alloy) and DMU16 (Ferro Alloys Corporation) have their up and down changes in efficiency, which again notably made some abrupt in technical changes over the beginning years and then go smoothly with the overall trend of the companies in the industry.

Figure 2 shows frontier change over the period 2010 to 2014.

Finally, the most important element in the performance evaluation of the industry is Malmquist Productivity Index (MPI), which is clearly indicated in Table 15 and Figure 3. Overall, most of the companies have done well in their performance when the indices are larger than $1(>1)$. 


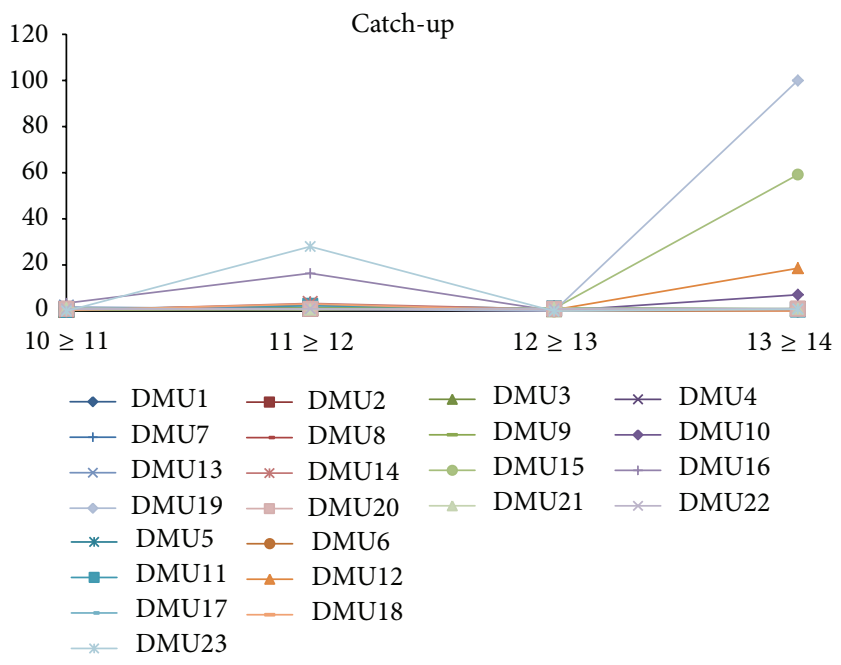

FIGURE 1: Efficiency change of the India mining industry.

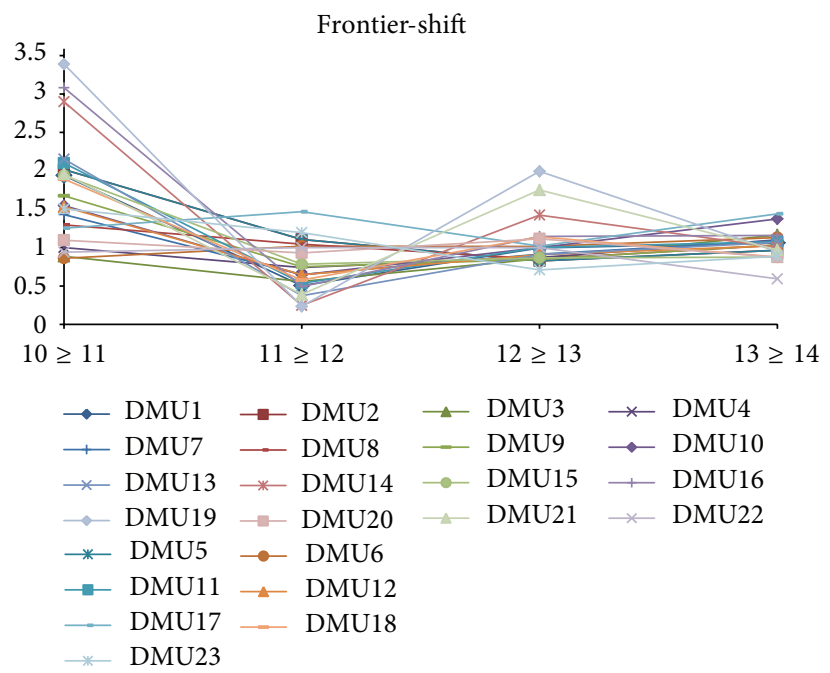

FIgURE 2: Frontier change over the period 2010 to 2014.

Malmquist

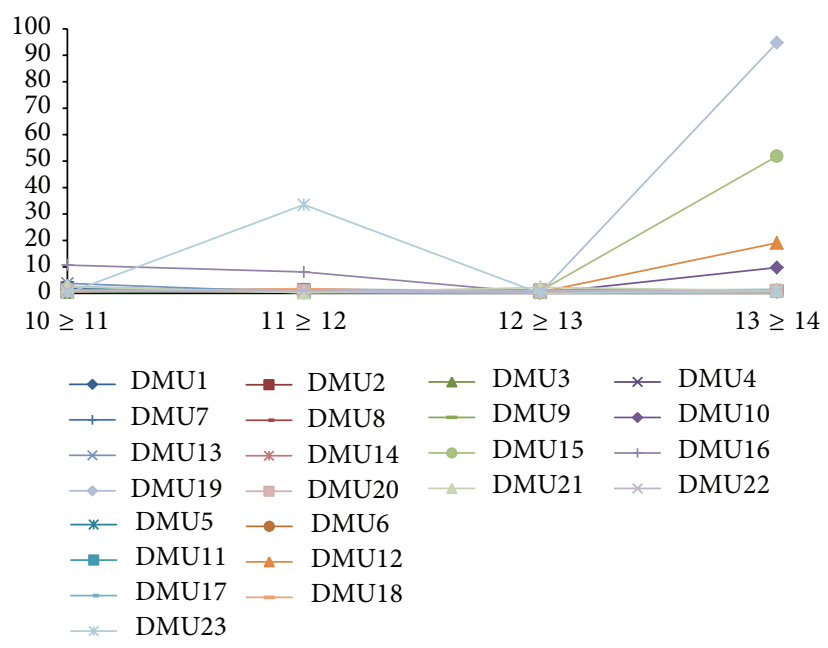

Figure 3: Productivity index (MPI) change over the period 2010 to 2014. 
TABLE 12: Paired samples test.

Paired differences

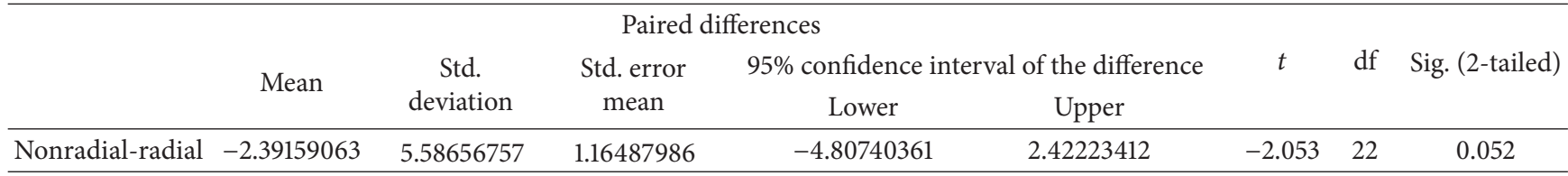

TABLE 13: Efficiency (catch-up) change over the period 2010 to 2014

\begin{tabular}{|c|c|c|c|c|c|}
\hline Catch-up & $2010=>2011$ & $2011=>2012$ & $2012=>2013$ & $2013=>2014$ & Average \\
\hline DMU1 & 0.797164 & 2.59442 & 1.032442 & 0.791229 & 1.303814 \\
\hline DMU2 & 1 & 1 & 1 & 1 & 1 \\
\hline DMU3 & 0.552856 & 1.431211 & 0.828415 & 0.933791 & 0.936568 \\
\hline DMU4 & 1.032759 & 1.465646 & 1.182876 & 0.92438 & 1.151415 \\
\hline DMU5 & 1 & 1 & 1 & 1 & 1 \\
\hline DMU6 & 0.937901 & 1.378819 & 0.825954 & 0.845968 & 0.997161 \\
\hline DMU7 & 0.471145 & 0.905615 & 1.359682 & 0.909135 & 0.911394 \\
\hline DMU8 & 1.039128 & 1.061079 & 1.013052 & 0.90127 & 1.003632 \\
\hline DMU9 & 0.319083 & 1.477367 & 1.364119 & 0.962369 & 1.030734 \\
\hline DMU10 & 0.999124 & 0.785092 & 0.073613 & 7.096281 & 2.238527 \\
\hline DMU11 & 0.536717 & 2.330671 & 1.185882 & 0.705593 & 1.189716 \\
\hline DMU12 & 0.62322 & 0.975688 & 0.562964 & 18.58698 & 5.187213 \\
\hline DMU13 & 1.750376 & 0.973694 & 0.937314 & 0.708907 & 1.092573 \\
\hline DMU14 & 0.33748 & 3.352059 & 0.825772 & 0.996476 & 1.377947 \\
\hline DMU15 & 0.578274 & 0.584548 & 1.151855 & 59.18462 & 15.37482 \\
\hline DMU16 & 3.469142 & 16.39564 & 0.107797 & 1.053356 & 5.256485 \\
\hline DMU17 & 0.980244 & 1.060022 & 1.004774 & 1.033946 & 1.019747 \\
\hline DMU18 & 0.33236 & 3.121029 & 0.205235 & 0.042027 & 0.925162 \\
\hline DMU19 & 0.792118 & 0.940237 & 0.065941 & 100 & 25.44957 \\
\hline DMU20 & 1 & 1 & 1 & 1 & 1 \\
\hline DMU21 & 1.281971 & 0.699462 & 1.269806 & 1.060911 & 1.078037 \\
\hline DMU22 & 1 & 1 & 1 & 1 & 1 \\
\hline DMU23 & 0.05752 & 28.01865 & 0.010044 & 0.880411 & 7.241656 \\
\hline Average & 0.908199 & 3.197868 & 0.826415 & 8.765985 & 3.424616 \\
\hline Max & 3.469142 & 28.01865 & 1.364119 & 100 & 25.44957 \\
\hline Min & 0.05752 & 0.584548 & 0.010044 & 0.042027 & 0.911394 \\
\hline SD & 0.670389 & 6.293493 & 0.434709 & 23.49756 & 5.821886 \\
\hline
\end{tabular}

Figure 3 shows that DMU19, DMU15, DMU12, and DMU10 have slight changes over the beginning years; however, their MPI scores are going up sharply in the period of 2013-2014. DMU23 was shaking over the period 2010-2013, and finally in 2014 it goes to 0 . The rest of the companies have also increased and decreased in their MPI scores but very slightly.

$\operatorname{GM}(1,1)$ was used to forecast the future performance of the industry for the next four years (2015-2018) based on the results of Malmquist Productivity Index collected from 20102014. MPI change over the forecasted future period is done by Malmquist nonradial $\mathrm{O}-\mathrm{V}$ model, which is illustrated in Table 16 and Figure 4. In the forecasting period (2014-2018), most of the MPIs of companies can reach the "efficiency" level or positive change year over year. Although some of companies still work inefficiently, we obviously see the stable changes of mining industry in the future period.
In the future, DMU23 and DMU18 will show a rocketfuelled increase in their MPI up to the level of over 90 in the period of 2015-2016; however, in the next two periods, 2016-2017 and 2017-2018, they keep going down at around 1 of efficiency level.

Besides, we noticed that DMU7 will show its better performance in the future. Even though MPI scores of DMU7 will go down at around 1 of efficiency level in the period of 2015-2016, the scores will gradually keep going up in the next two periods, 2016-2017 and 2017-2018. The rest of the companies have also increased and decreased in their MPI scores but very slightly for the whole period.

\section{Conclusion}

In this study, the authors attempt to measure productive efficiency of 23 mining companies in India. The data covered 
TABLE 14: Technical (Frontier) change over the period 2010 to 2014.

\begin{tabular}{|c|c|c|c|c|c|}
\hline Frontier & $2010=>2011$ & $2011=>2012$ & $2012=>2013$ & $2013=>2014$ & Average \\
\hline DMU1 & 1.939121602 & 0.504629603 & 0.996300267 & 1.06244232 & 1.125623448 \\
\hline DMU2 & 2.015905198 & 1.10571636 & 0.82675343 & 0.964586441 & 1.228240357 \\
\hline DMU3 & 0.886326283 & 0.558239264 & 0.854416817 & 1.163988937 & 0.865742825 \\
\hline DMU4 & 1.000476644 & 0.741267265 & 0.870616146 & 1.100278455 & 0.928159628 \\
\hline DMU5 & 2.015905198 & 1.10571636 & 0.82675343 & 0.964586441 & 1.228240357 \\
\hline DMU6 & 0.861710382 & 1.018301532 & 1.014340243 & 1.130278256 & 1.006157603 \\
\hline DMU7 & 1.430118052 & 0.647589191 & 0.913795938 & 1.088321211 & 1.019956098 \\
\hline DMU8 & 1.295194694 & 1.04381169 & 0.851005728 & 1.030519595 & 1.055132927 \\
\hline DMU9 & 1.674444152 & 0.750046037 & 0.847017068 & 1.035738188 & 1.076811361 \\
\hline DMU10 & 1.546932314 & 0.645062431 & 1.000197233 & 1.374187295 & 1.141594818 \\
\hline DMU11 & 2.100229237 & 0.534814478 & 1.001097942 & 1.07648664 & 1.178157074 \\
\hline DMU12 & 1.531741397 & 0.645525171 & 0.906630074 & 1.025145953 & 1.027260649 \\
\hline DMU13 & 2.152459816 & 0.373558899 & 0.909365366 & 1.066824671 & 1.125552188 \\
\hline DMU14 & 2.899201454 & 0.247983445 & 1.423331621 & 1.003169142 & 1.393421416 \\
\hline DMU15 & 1.937809329 & 0.783532361 & 0.866668618 & 0.875736904 & 1.115936803 \\
\hline DMU16 & 3.081717159 & 0.493051054 & 1.145757947 & 1.157888408 & 1.469603642 \\
\hline DMU17 & 1.252853816 & 1.467478027 & 1.019956535 & 1.439608261 & 1.29497416 \\
\hline DMU18 & 1.891744104 & 0.577088174 & 1.14044083 & 0.876535166 & 1.121452069 \\
\hline DMU19 & 3.388616607 & 0.23432004 & 1.99304714 & 0.947786186 & 1.640942493 \\
\hline DMU20 & 1.095824176 & 0.931013697 & 1.11412316 & 0.874974664 & 1.003983924 \\
\hline DMU21 & 1.959059779 & 0.389859532 & 1.749978617 & 0.969696801 & 1.267148682 \\
\hline DMU22 & 0.940015391 & 1 & 1 & 0.593251026 & 0.883316604 \\
\hline DMU23 & 1.503821085 & 1.195321455 & 0.709459198 & 0.888087167 & 1.074172226 \\
\hline Average & 1.756575125 & 0.738866351 & 1.042654493 & 1.030874701 & 1.142242668 \\
\hline Max & 3.388616607 & 1.467478027 & 1.99304714 & 1.439608261 & 1.640942493 \\
\hline Min & 0.861710382 & 0.23432004 & 0.709459198 & 0.593251026 & 0.865742825 \\
\hline SD & 0.681955633 & 0.321859374 & 0.302317354 & 0.171291998 & 0.184302772 \\
\hline
\end{tabular}

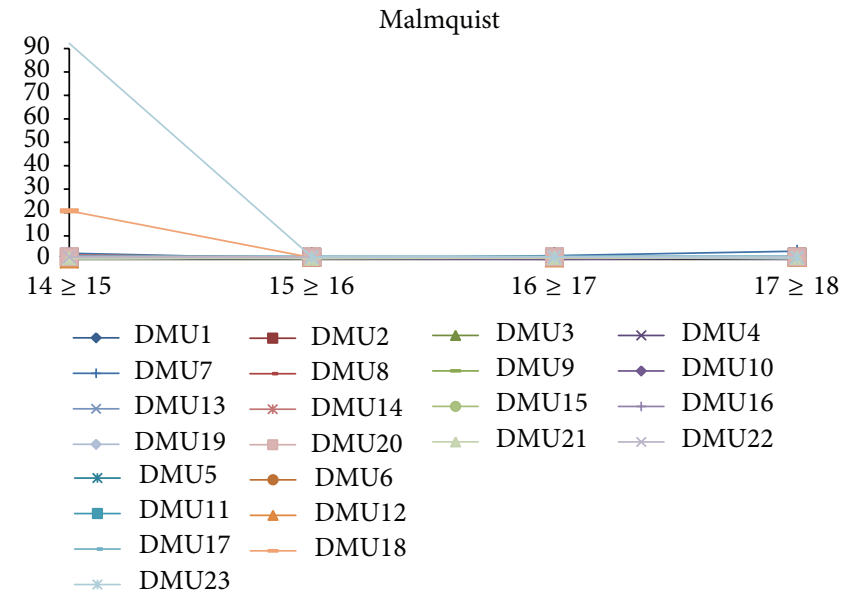

FIgURE 4: Productivity index (MPI) change over the period 2014-2018.

the period from 2010 to 2014 and were collected from the websites of Bombay Stock Exchange and Money Control that contain the financial data of these companies. The results of rankings from super SBM model indicated that the ranking of the Indian mining industries is tending to change in a very slight manner on yearly basis. However, the majority of these companies are maintaining their "efficient" levels even after yearly changes on their financial nature.

The results also clearly stated out that during the period 2010-2014 the Coal India Ltd (DMU17), National Mineral Development Corporation (DMU6), Hindalco Industry (DMU8), Maithan Alloys (DMU14), and Sandur Manganese 
TABLE 15: Productivity index (Malmquist-MPI) change over the period 2010 to 2014.

\begin{tabular}{|c|c|c|c|c|c|}
\hline Malmquist & $2010=>2011$ & $2011=>2012$ & $2012=>2013$ & $2013=>2014$ & Average \\
\hline DMU1 & 1.545797114 & 1.309221254 & 1.028622365 & 0.840635021 & 1.181068938 \\
\hline DMU2 & 2.015905198 & 1.10571636 & 0.82675343 & 0.964586441 & 1.228240357 \\
\hline DMU3 & 0.490011136 & 0.798958453 & 0.70781135 & 1.08692264 & 0.770925894 \\
\hline DMU4 & 1.033251374 & 1.086435341 & 1.029830568 & 1.01707566 & 1.041648236 \\
\hline DMU5 & 2.015905198 & 1.10571636 & 0.82675343 & 0.964586441 & 1.228240357 \\
\hline DMU6 & 0.808198851 & 1.404053105 & 0.837798856 & 0.956179723 & 1.001557634 \\
\hline DMU7 & 0.673792601 & 0.586466544 & 1.242472165 & 0.989430703 & 0.873040503 \\
\hline DMU8 & 1.345873019 & 1.10756626 & 0.862113 & 0.928776162 & 1.06108211 \\
\hline DMU9 & 0.53428624 & 1.108093608 & 1.155431935 & 0.996761875 & 0.948643415 \\
\hline DMU10 & 1.545577938 & 0.506433239 & 0.073627354 & 9.751618997 & 2.969314382 \\
\hline DMU11 & 1.127229082 & 1.246476571 & 1.187183531 & 0.759561202 & 1.080112596 \\
\hline DMU12 & 0.954612304 & 0.629831235 & 0.510399744 & 19.05436823 & 5.287302877 \\
\hline DMU13 & 3.767615006 & 0.363731928 & 0.85236047 & 0.75627938 & 1.434996696 \\
\hline DMU14 & 0.978423652 & 0.831255052 & 1.175347113 & 0.999633621 & 0.99616486 \\
\hline DMU15 & 1.120585111 & 0.458012204 & 0.998276177 & 51.83015232 & 13.60175645 \\
\hline DMU16 & 10.69091327 & 8.083889578 & 0.123509827 & 1.219668695 & 5.029495342 \\
\hline DMU17 & 1.228103042 & 1.555559234 & 1.024825525 & 1.488477741 & 1.324241385 \\
\hline DMU18 & 0.628739377 & 1.801108782 & 0.234058131 & 0.036837705 & 0.675185999 \\
\hline DMU19 & 2.684183223 & 0.220316389 & 0.131423949 & 94.77861863 & 24.45363555 \\
\hline DMU20 & 1.095824176 & 0.931013697 & 1.11412316 & 0.874974664 & 1.003983924 \\
\hline DMU21 & 2.511457379 & 0.272691989 & 2.222132539 & 1.028761724 & 1.508760908 \\
\hline DMU22 & 0.940015391 & 1 & 1 & 0.593251026 & 0.883316604 \\
\hline DMU23 & 0.086500142 & 33.49129408 & 0.01 & 0.781881615 & 8.59241896 \\
\hline Average & 1.731426079 & 2.652340925 & 0.833689331 & 8.37821914 & 3.398918869 \\
\hline Max & 10.69091327 & 33.49129408 & 2.222132539 & 94.77861863 & 24.45363555 \\
\hline Min & 0.086500142 & 0.220316389 & 0.01 & 0.036837705 & 0.675185999 \\
\hline SD & 2.119828504 & 6.898136352 & 0.49641247 & 21.87797994 & 5.533163948 \\
\hline
\end{tabular}

Iron Ores (DMU21) always keep the ranking of the top five companies among 23 DMUs regarding the performance scores.

However, for the future period 2015-2018 (forecasting with $\operatorname{GM}(1,1)$ ), although the Coal India Ltd. (DMU17), National Mineral Development Corporation (DMU6), and Hindalco Industry (DMU8) are still on top, Maithan Alloys (DMU14) and Sandur Manganese Iron Ores (DMU21) will be replaced by Hindustan Zinc Limited (DMU9) and Gujarat Mineral Development Corporation (DMU11) on the top performance scores.

Furthermore, Facor Alloys (DMU19), 20 Microns (DMU18), and Impex Ferro Tech (DMU15) were noticed as the inefficient companies which have the lowest score of performance over the past-present-future period. These DMUs need urgent action for improving the performance over partners in the research industry.

The results of Wilcoxon test (Table 12) show that there are no differences between the Malmquist radial and Malmquist nonradial models, so the authors used Malmquist nonradial model as a tool for measuring the productivity change of coal mining sectors during different time periods (2010-2014). The results have revealed that all companies in the mining industry have not shown sudden changes on their scores over the past-present-future period. This indicates that, although suffering from the financial crisis, the industry just only shows slight changes on the score performance, except some little changes between companies which are explained in the previous section.

After applying a hybrid DEA and Grey system theory on analyzing performance of 23 Indian mining companies, the authors have found many meaningful and noticeable results for this industry. Firstly, it minimizes the methodology limitation problems by deeply employing the best sides of an integration method. Secondly, it provides detailed insights of Indian mining industry as it is the core of the economy. Furthermore, according to forecasted MPI, companies with inefficient level $(<1)$ need to be positive in changing or improving their management activities, business trends, size, or any other methods to make progress in the future time. By completing this research, the authors are aiming to suggest this case as a better model of performance analysis among the decision makers of variety of industries.

\section{Conflict of Interests}

The authors declare that there is no conflict of interests regarding the publication of this paper. 
TABLE 16: MPI change over the forecasted period 2014 to 2018.

\begin{tabular}{|c|c|c|c|c|c|}
\hline Malmquist & $2014=>2015$ & $2015=>2016$ & $2016=>2017$ & $2017=>2018$ & Average \\
\hline DMU1 & 1.155377644 & 1.036943532 & 1.047454651 & 1.05440683 & 1.073545665 \\
\hline DMU2 & 0.941154142 & 0.941808396 & 0.946455953 & 0.962595312 & 0.948003451 \\
\hline DMU3 & 0.709387778 & 0.807083952 & 0.803241667 & 0.805875709 & 0.781397276 \\
\hline DMU4 & 1.050990953 & 1.032766941 & 1.026102588 & 1.029176837 & 1.03475933 \\
\hline DMU5 & 0.941154142 & 0.941808396 & 0.946455953 & 0.962595312 & 0.948003451 \\
\hline DMU6 & 0.953788767 & 0.950848108 & 0.979051059 & 1.00181251 & 0.971375111 \\
\hline DMU7 & 2.608808968 & 0.328959024 & 1.575407484 & 3.50365797 & 2.004208362 \\
\hline DMU8 & 1.014221762 & 1.030899367 & 0.995572443 & 0.970905349 & 1.00289973 \\
\hline DMU9 & 1.150544925 & 1.078417389 & 1.090671738 & 1.085395159 & 1.101257303 \\
\hline DMU10 & 1.940672028 & 0.340427772 & 0.02251981 & 0.560101027 & 0.715930159 \\
\hline DMU11 & 1.276180243 & 1.08751783 & 1.050084819 & 1.036211195 & 1.112498522 \\
\hline DMU12 & 0.169997844 & 0.875829328 & 0.611861239 & 0.784462215 & 0.610537657 \\
\hline DMU13 & 0.226873084 & 0.591108199 & 0.578352236 & 0.577229556 & 0.493390769 \\
\hline DMU14 & 1.869237094 & 0.973919273 & 1.024055164 & 1.039153116 & 1.226591162 \\
\hline DMU15 & 0.031602939 & 0.948432575 & 0.500567996 & 0.929526595 & 0.602532526 \\
\hline DMU16 & 0.873867965 & 1.0795813 & 1.083671912 & 1.086164776 & 1.030821488 \\
\hline DMU17 & 1.403725525 & 1.326313141 & 1.351549367 & 1.385723238 & 1.366827818 \\
\hline DMU18 & 20.67554712 & 0.718647781 & 0.618935022 & 0.652760872 & 5.666472699 \\
\hline DMU19 & 0.250804329 & 0.681482367 & 0.957742973 & 0.138790391 & 0.507205015 \\
\hline DMU20 & 1.028020624 & 0.985195792 & 0.985199371 & 0.985197534 & 0.99590333 \\
\hline DMU21 & 0.453076135 & 0.288464627 & 0.634050426 & 0.626207563 & 0.500449688 \\
\hline DMU22 & 1 & 0.915095672 & 1 & 0.818778182 & 0.933468464 \\
\hline DMU23 & 92.21332042 & 1 & 1 & 0.823358538 & 23.75916974 \\
\hline Average & 5.823406714 & 0.867893511 & 0.905608864 & 0.992177643 & 2.147271683 \\
\hline Max & 92.21332042 & 1.326313141 & 1.575407484 & 3.50365797 & 23.75916974 \\
\hline Min & 0.031602939 & 0.288464627 & 0.02251981 & 0.138790391 & 0.493390769 \\
\hline SD & 19.28212645 & 0.264628932 & 0.311183931 & 0.601826474 & 4.823734506 \\
\hline
\end{tabular}

\section{References}

[1] K. Singh and K. Kalirajan, "A decade of economic reforms in India: the mining sector," Resources Policy, vol. 29, no. 3-4, pp. 139-151, 2004.

[2] A. Das, "Who extracts minerals more efficiently-public or private firms? A study of Indian mining industry," Journal of Policy Modeling, vol. 34, no. 5, pp. 755-766, 2012.

[3] M. Kulshreshtha and J. K. Parikh, "Study of efficiency and productivity growth in opencast and underground coal mining in India: a DEA analysis," Energy Economics, vol. 24, no. 5, pp. 439-453, 2002.

[4] H. Fang, J. Wu, and C. Zeng, "Comparative study on efficiency performance of listed coal mining companies in China and the US," Energy Policy, vol. 37, no. 12, pp. 5140-5148, 2009.

[5] M. Kulshreshtha and J. K. Parikh, "A study of productivity in the Indian coal sector," Energy Policy, vol. 29, no. 9, pp. 701-713, 2001.

[6] Y. Kasap, A. Konuk, R. N. Gasimov, and A. M. Kiliç, "The effects of non-controllable factors in efficiency evaluation of Turkish coal enterprises," Energy Exploration and Exploitation, vol. 25, no. 6, pp. 429-450, 2007.

[7] X. Xue, Q. Shen, Y. Wang, and J. Lu, "Measuring the productivity of the construction industry in China by using DEAbased malmquist productivity indices," Journal of Construction Engineering and Management, vol. 134, no. 1, pp. 64-71, 2008.
[8] I. E. Tsolas, "Performance assessment of mining operations using nonparametric production analysis: a bootstrapping approach in DEA," Resources Policy, vol. 36, no. 2, pp. 159-167, 2011.

[9] H. Berkman and V. R. Eleswarapu, "Short-term traders and liquidity :: a test using Bombay Stock Exchange. Paper presented at the WFA and the APFA/PACAP Conferences," Journal of financial Economics, vol. 47, no. 3, pp. 339-355, 1998.

[10] M. Jain, P. L. Meena, and T. N. Mathur, "Impact of foreign institutional investment on stock market with special reference to BSE, a study of last one decade," Asian Journal of Research in Banking and Finance, vol. 2, no. 4, pp. 31-47, 2012.

[11] C. N. Wang, N. T. Nguyen, and T. T. Tran, "Integrated DEA models and grey system theory to evaluate past-to-future performance: a case of Indian electricity industry," The Scientific World Journal, vol. 2014, Article ID 638710, 23 pages, 2014.

[12] J. Zhu, "Multi-factor performance measure model with an application to Fortune 500 companies," European Journal of Operational Research, vol. 123, no. 1, pp. 105-124, 2000.

[13] T.-Y. Chen and L.-H. Chen, "DEA performance evaluation based on BSC indicators incorporated: the case of semiconductor industry," International Journal of Productivity and Performance Management, vol. 56, no. 4, pp. 335-357, 2007.

[14] A. Charnes, W. W. Cooper, and E. Rhodes, "Measuring the efficiency of decision making units," European Journal of Operational Research, vol. 2, no. 6, pp. 429-444, 1978. 
[15] R. Banker, A. Charnes, and W. W. Cooper, "Some models for estimating technical and scale inefficiency in data envelopment analysis," Management Science, vol. 30, no. 9, pp. 1078-1092, 1984.

[16] R. Fare, S. Grossfopf, and C. A. K. Lovell, Production Frontiers, Cambridge University Press, New York, NY, USA, 1994.

[17] K. A. Tone, "Slacks-based measure of efficiency in data envelopment analysis," European Journal of Operational Research, vol. 130, no. 3, pp. 498-509, 2001.

[18] K. A. Tone, "A slacks-based measure of super-efficiency in data envelopment analysis," European Journal of Operational Research, vol. 143, no. 1, pp. 32-41, 2002.

[19] K. F. Lam, H. W. Mui, and H. K. Yuen, "A note of minimizing absolute percentage error in combined forecasts," Computers and Operations Research, vol. 28, no. 11, pp. 1141-1147, 2001.

[20] R. J. Hyndman and A. B. Koehler, "Another look at measures of forecast accuracy," International Journal of Forecasting, vol. 22, no. 4, pp. 679-688, 2006.

[21] W. Chia-Nan and N. N. Ty, "Forecasting the manpower requirement in Vietnamese tertiary institutions," Asian Journal of Empirical Research, vol. 3, no. 5, pp. 563-575, 2013.

[22] F.-Y. Lo, C.-F. Chien, and J. T. Lin, "A DEA study to evaluate the relative efficiency and investigate the district reorganization of the Taiwan Power Company," IEEE Transactions on Power Systems, vol. 16, no. 1, pp. 170-178, 2001.

[23] L. M. Seiford and J. Zhu, "Modeling undesirable factors in efficiency evaluation," European Journal of Operational Research, vol. 142, no. 1, pp. 16-20, 2002.

[24] N. K. Avkiran, "Association of DEA super-efficiency estimates with financial ratios: investigating the case for Chinese banks," Omega, vol. 39, no. 3, pp. 323-334, 2011.

[25] Y. Chen and H. D. Sherman, "The benefits of non-radial vs. radial super-efficiency DEA: an application to burden-sharing amongst NATO member nations," Socio-Economic Planning Sciences, vol. 38, no. 4, pp. 307-320, 2004. 


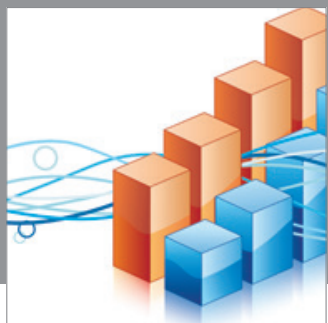

Advances in

Operations Research

mansans

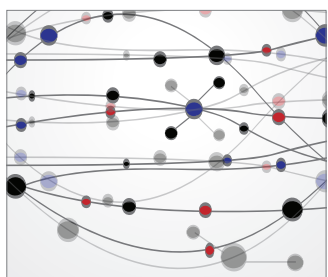

The Scientific World Journal
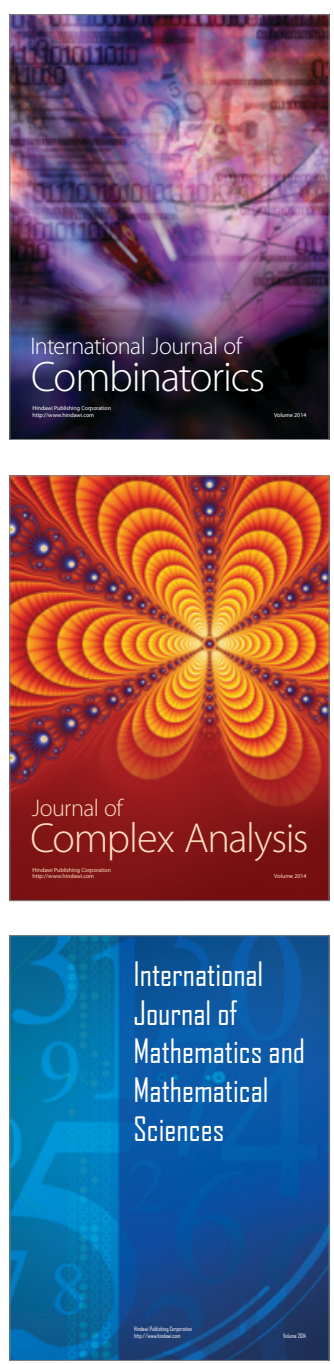
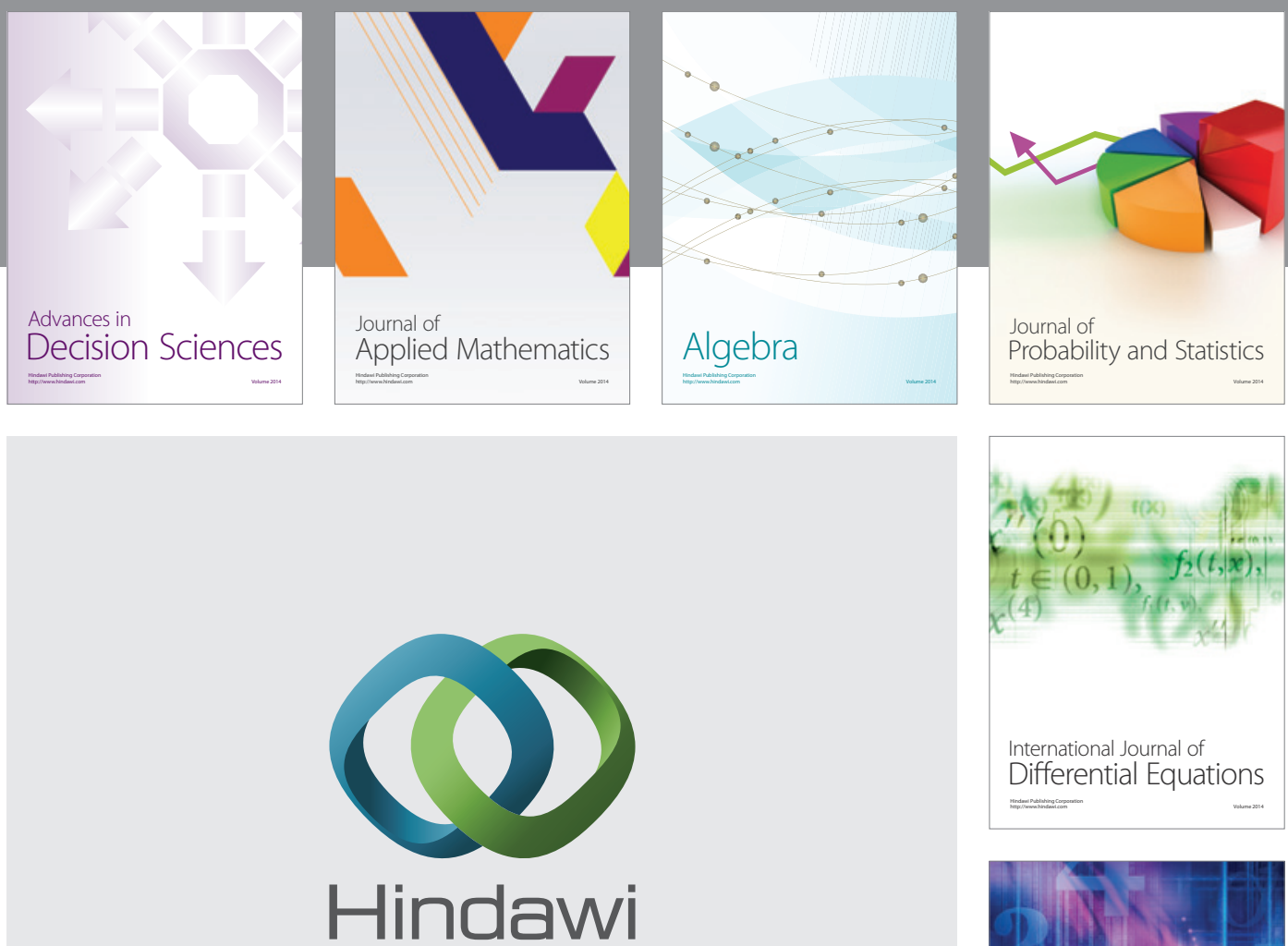

Submit your manuscripts at http://www.hindawi.com
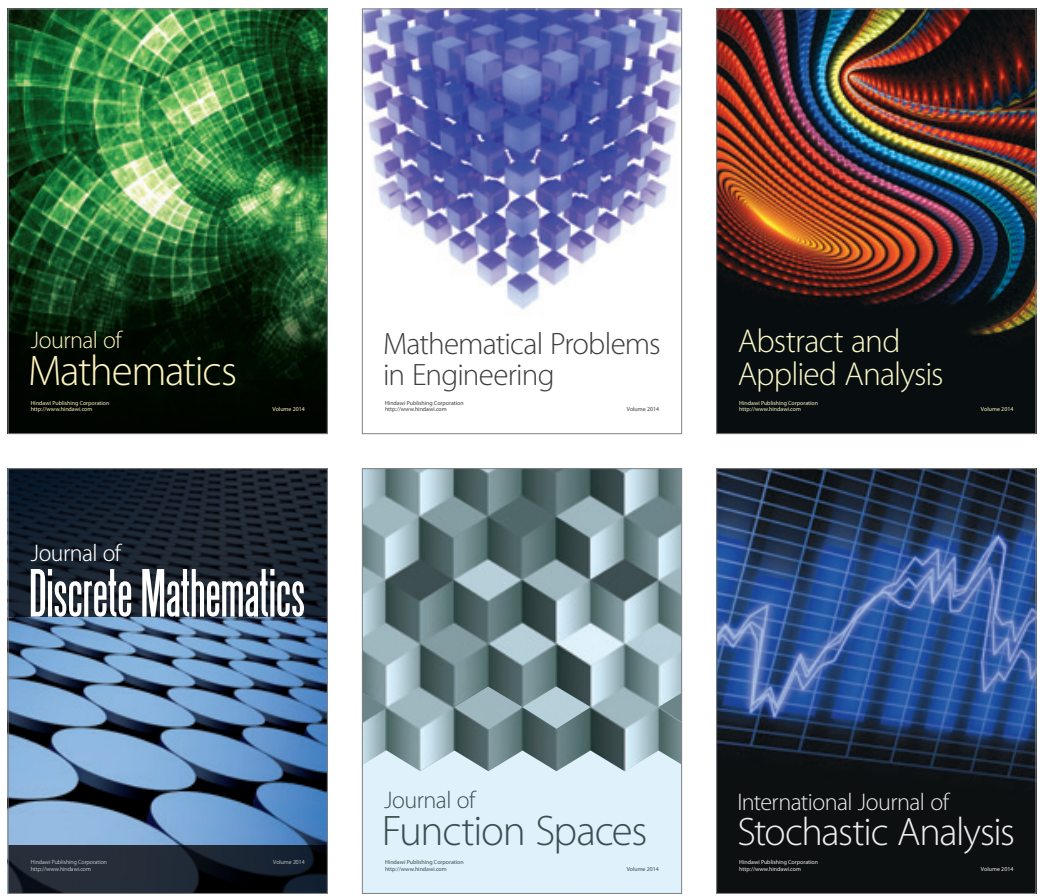

Journal of

Function Spaces

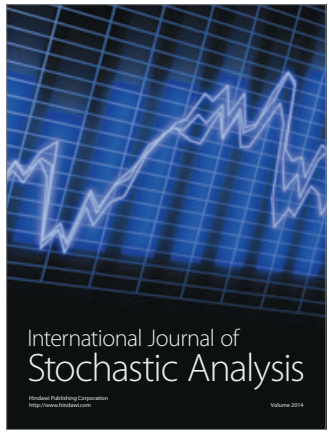

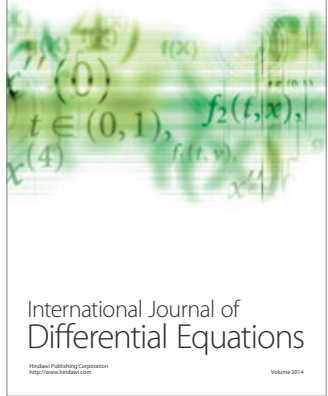
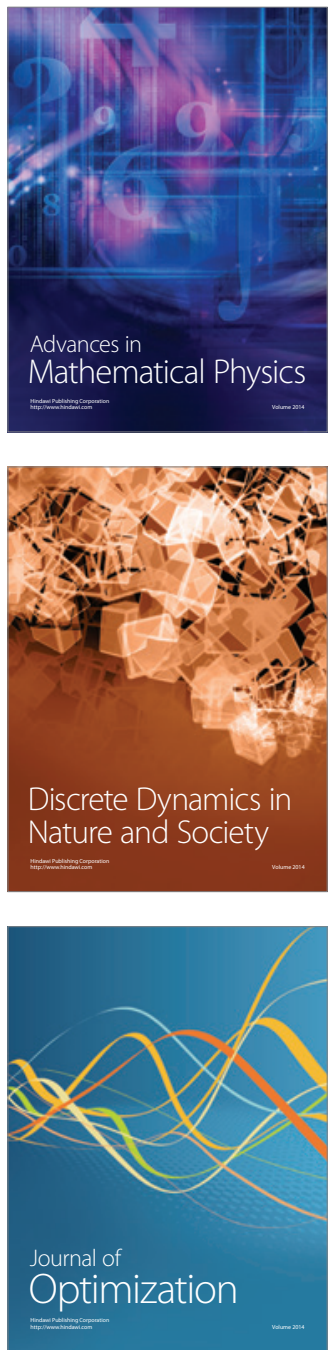